\title{
Edukacja i resocjalizacja więziennych matek przez macierzyństwo
}

\section{Education and Resocialisation of Prison Mothers through Motherhood}

\begin{abstract}
From the first moments of life, children are subject to a learning process. The first role model for them is the mother from whom they learn the basics. They lean words, modes of behaviour and also how to function in society. If this is not learned in the early years of development, the socialisation process will certainly be disturbed. An analysis of the biography of female prisoners shows that their socialisation in most cases was disturbed and so they duplicated abnormal patterns in adulthood. Often, some mothers neglected their maternity duties before going to prison, and those who gave birth to children in isolation were not sufficiently (or not at all) prepared to perform this role. Education as an integral part of social rehabilitation plays a key role here. Convicted mothers serving a prison sentence together with children have the opportunity to learn to correct attitudes and behaviour towards their children by participating in numerous forms of assistance and workshop. They should undergo the education process along with their children who will need to find their place in society under conditions of freedom. Education and resocialisation through the love of a mother for her child is an effective method for inclusion.
\end{abstract}

Key words: education, learning and socialisation, social rehabilitation through love, isolation motherhood, inclusion.

* Barbara Toroń-Fórmanek (ORCID oooo-0003-1699-3679) - doktor habilitowany, profesor Uniwersytetu Zielonogórskiego, kierownik Pracowni Resocjalizacji i Pedagogiki Penitencjarnej na Wydziale Pedagogiki, Psychologii i Socjologii uZ, kontakt: btoron@wp.pl. 


\section{Socjalizacyjne znaczenie matki}

W procesie uczenia się jednostki ludzkiej możemy wyodrębnić stałe elementy takie jak: rodzina, krąg przyjaciół, szkoła, zakład pracy, społeczność lokalna i inne skupiska społeczne. Struktura społeczna bezsprzecznie oddziałuje na nasze myśli, sposób postrzegania, emocje, działania oraz interakcje. W procesie socjalizacji jednak pojawiają się zmienne takie jak: wiedza społeczna (wartości, normy i postawy społeczne), sposoby jej przekazu, czyli mechanizmy socjalizacji (mechanizm nacisku zewnętrznego, naśladownictwa i nacisku wewnętrznego), nadawcy treści społecznych i odbiorcy przekazywanej wiedzy. To właśnie one decydują o tym, że proces socjalizacji przebiega tak różnie u każdego człowieka.

Macierzyństwo i jego społeczne funkcje uważać można za rodzaj służby wobec rodzaju ludzkiego'. Rodząc dzieci, kobieta zapewnia stałość biologicznego istnienia społeczeństwa, ale także - co istotniejsze - trwałość społeczną i kulturową. Ponadto będąc najczęściej główną opiekunką i wychowawczynią dzieci, to właśnie matka w głównej mierze przyczynia się do kształtowania obrazu procesu socjalizacji w jego wczesnych fazach, a wiadomym jest, że socjalizacja pierwotna w znacznej mierze rozstrzyga o obrazie biograficznym jednostki.

Danuta Lalak twierdzi, że kształt i charakter ludzkiego życia nie jest określony przede wszystkim prawami biologicznymi (genetyka), lecz jest determinowany przez kulturę i instytucje społeczne, czyli specyficzny ład ekonomiczny, normatywny, edukacyjny ${ }^{2}$. Tym samym więc życie każdego człowieka ,jest przede wszystkim procesem przystosowania się do wzorów i zasad przekazywanych przez tradycję społeczności, w której żyje"3. Niewątpliwie fundamentalną rolę odgrywa w tej materii edukacja. Paradygmat badań biograficznych traktuje życie człowieka jako proces właśnie edukacyjny i formacyjny, celowy, a zarazem spontaniczny obejmujący socjalizację i wychowanie ${ }^{4}$.

$\mathrm{Na}$ proces socjalizacji człowieka decydujący wpływ mają warunki przynależne do trzech sfer: fizycznej (biologicznej), społecznej i psychologicznej. Glen

1 D. Sobczyńska, Macierzyństwo: wartości i dylematy, w: Humanistyka i płeć. Studia kobiece z psychologii, filozofii i historii, red. J. Miluska, E. Pakszys, Poznań 1999, s. 71.

2 D. Lalak, Życie jako biografia. Podejście biograficzne w perspektywie pedagogicznej, Warszawa 2010, s. 138.

3 R. Benedict, Wzory kultury, przeł. J. Prokopiuk, Warszawa 2002, s. 79.

4 D. Lalak, Życie jako biografia, s. 90. 
Walters zakłada, że interakcje jednostki ze środowiskiem, zwłaszcza w pierwszych czterech-pięciu latach życia, warunkują jej sposób zachowania w przyszłości. Zwracał na to uwagę także Jonathan H. Turner, który uważał, że:

Nasze życie jest nieustannym poruszaniem się w strukturach społecznych, takich jak rodzina, krąg przyjaciół, szkoła, zakład pracy, społeczność lokalna i inne skupiska społeczne. To, czym jesteśmy jako jednostki, stanowi wynik owych strukturalnych przynależności. [...] struktura społeczna ma moc oddziaływania na nasze myśli, sposób postrzegania, emocje, działania oraz interakcje $e^{5}$.

Samemu terminowi „socjalizacja” nadaje się różną treść oraz zakres w zależności od orientacji, np. antropologicznej, socjologicznej, pedagogicznej czy psychologicznej ${ }^{6}$. W ujęciu socjologicznym:

[...] socjalizacja jest procesem wyłaniania się, kształtowania i rozwoju osobowości ludzkiej. Proces ten aktualizuje się z jednej strony w zależności od organizmu jednostki i w interakcjach z nim, z drugiej zaś w zależności od i w interakcjach ze społecznymi i ekologicznymi warunkami życiowymi, istniejącymi w konkretnym, historycznie określonym społeczeństwie?.

Liczne ujęcia psychologiczne definiują socjalizację jako:

[...] proces internalizacji wartości i norm, proces introjekcji superego rodziców, proces kształtowania się pozytywnych cech charakteru, proces kształtowania się prawidłowej samooceny i realistycznego poziomu aspiracji, proces kształtowania się postaw prospołecznych [...], proces kształtowania się struktur poznawczych, głównie moralnych ${ }^{8}$.

Biorąc pod uwagę powyższe ujęcia, można wysnuć konkluzję, iż socjalizacja jest specyficznym procesem dostosowywania się jednostki do życia społecznego, które Mieczysław Ciosek definiuje jako

5 J. H. Turner, Socjologia. Podstawowe pojęcia i ich zastosowanie, przeł. E. Różalska, Poznań 200o, s. 66.

6 M. Ciosek, Psychologia sq̨dowa i penitencjarna, wyd. 2, Warszawa 2003, s. 38.

7 K. Hurrelmann, Struktura społeczna a rozwój osobowości, przeł. M. Roguszka, Poznań 1994, s. 16.

8 M. Ciosek, Psychologia sądowa i penitencjarna, s. 38. 
[...] proces gromadzenia doświadczenia społecznego, na które składa się wiedza jednostki o tym, czego społeczeństwo - ściślej zaś grupy społeczne i instytucje - oczekują od niej w określonych sytuacjach, i o tym, czego sama może oczekiwać od innych ludzi i społeczeństwa9.

Owe treści społeczne, które jednostka przyswaja w procesie socjalizacji, mają ułatwić jej życie w grupie społecznej oraz rozwój osobowości. Wymagania społeczne rzadko jednak realizowane są w wymiarze wzorcowym, dlatego więc społeczeństwo ustala swego rodzaju granicę, której „przekroczenie uważa za mniej lub bardziej groźny objaw niedostosowania społecznego i zaburzenie procesu socjalizacji”'10.

„Sukces bądź niepowodzenie socjalizacji - jak podkreśla Klaus Hurrelmann jest warunkowane odpowiedniością kompetencji działania, autokoncepcji i ukształtowanej tożsamości jednostki do zadań rozwojowych w danej biograficznej i społecznej sytuacji" ${ }^{\prime 11}$. Jeśli struktura i profil zachowań człowieka nie są wystarczająco rozwinięte, pojawia się tendencja do zachowań dewiacyjnych (psychicznych i społecznych), które stwarzają problemy w dalszym rozwoju osobowości człowieka. Dlatego też znaczącą rolę odgrywa w tym przypadku pomoc pozytywnych grup odniesienia (głównie rodziny). Jeśli ich zabraknie, jednostka bardzo często wkracza na grunt grup negatywnych, poszukując kontaktu z partnerami uznającymi lub podnoszącymi jej samoocenę. „Tworzy się wówczas lub stabilizuje

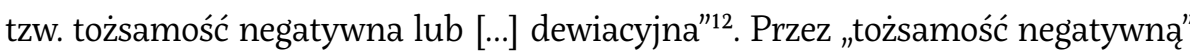
Alina Szczurek-Boruta rozumie: „tożsamość przewrotnie opartą na wszystkich identyfikacjach i rolach, które w pewnych stadiach krytycznych rozwoju jednostki były jej przedstawiane jako niepożądane czy niebezpieczne, choć dość realne"13. Składowe tożsamości negatywnej stanowią zatem wszystkie obrazy siebie diametralnie przeciwne wartościom dominującym w procesie socjalizacji.

9 Tamże, s. 39.

10 Tamże, s. 59.

11 K. Hurrelmann, Struktura społeczna a rozwój osobowości, s. 140.

12 W. Kubiak-Krzywicka, Resocjalizacja jako konwersja tożsamości dewiacyjnej, w: Resocjalizacja - ciągłość i zmiana, red. M. Konopczyński, B. M. Nowak, Warszawa 2008, s. 153.

13 E. H. Erikson, Identity: Youth and Crisis. New York 1968, s. 205, cyt. za: A. Szczurek-Boruta, Zadania rozwojowe młodzieży i edukacyjne warunki ich wypetniania $w$ środowiskach zróżnicowanych kulturowo i gospodarczo: studium pedagogiczne, Katowice 2007 , s. 137 . 
Socjalizacyjne znaczenie matki polega na jej ciągłej obecności oraz wpływie na rozwój dziecka, zwłaszcza w okresie niemowlęcym. Matka stymuluje sposób zachowania się dziecka. Jej różnorodne działania, takie jak pokazywanie przedmiotów, nazywanie, demonstrowanie sposobów postępowania, ułatwiają one dziecku różnicowanie bodźców. Ona też chroni je przed przykrymi doświadczeniami ${ }^{14}$. Wpływ matki zaczyna działać jeszcze przed urodzeniem dziecka, głównie poprzez jej stosunek do niego. Po jego urodzeniu to ona zwykle jest osobą, która zapewnia dziecku podstawowe potrzeby, a poprzez to wytwarza poczucie bezpieczeństwa, pewność i stabilność emocjonalną. Związek matki z dzieckiem jest wielostronny, bogaty w treść i znamienny w swych skutkach. Matka spełnia ogromną rolę w życiu i rozwoju dziecka, dostarczając mu wzorów, modeli zaspokajania potrzeb, uczy też zachowania się w sytuacjach, gdy potrzeby nie mogą być zrealizowane, uczy dziecko dostrzegania i respektowania potrzeb innych ludzi. Wszechstronne oddziaływanie matki na dziecko (we wszystkich okresach jego życia) odbywa się w sposób świadomy jako zamierzona praca wychowawcza oraz oddziaływanie niezamierzone, wyrażające się w ich wzajemnych stosunkach i niejednokrotnie odgrywające w tych interakcjach dużo większą rolę ${ }^{15}$.

Niemożność wchodzenia w interakcje z matką, zerwane więzi macierzyńskie, zaburzenie funkcjonowania psychospołecznego duetu matka-dziecko stanowią niewątpliwie sytuację trudną. Na przykład Jerzy Modrzewski określa sytuację trudną jako:

[...] układ zdarzeń i komponujący się z nim układ warunków, których dopełnieniem stają się takie cechy podmiotowe jednostki bądź ich kategorii, które w społecznie wyznaczonym czasie uniemożliwiają jednostce (kategorii jednostek) ujawnienie posiadania kompetencji uczestnictwa społecznego według oczekiwanego społecznie wobec nich wzoru ${ }^{16}$.

Gdy zatem rola socjalizacyjna matki i domu rodzinnego zostanie zaburzona, jednostka wkroczyć może na drogę przestępstwa.

14 S. Lis, Proces socjalizacji dziecka w środowisku pozarodzinnym, Warszawa 1992, s. 60.

15 E. Napora, Cechy matek pożądane w wychowaniu dzieci, „Problemy Rodziny”, 1995, nr 1, s. 23-29.

16 J. Modrzewski, Prakseologiczne modele pomocy jako kulturowy wzór reakcji spotecznej na sytuację trudna, w: Koncepcje pedagogiki społecznej, red. T. Frąckowiak, Poznań 1996, s. 135. 


\section{Macierzyństwo a nieprawidłowe wzorce socjalizacyjne na podstawie badań metodą biograficzną}

Biografia to życie opisane, zrelacjonowane, co wynika z etymologii tego wyrazu - gr. bios - życie i gráphõ - piszę. Metoda biograficzna określana jest jako metoda polegająca na opisie i analizie przebiegu życia ludzkiego rozpatrywanego w kontekście określonego wycinka społecznej rzeczywistości, stanowi swego rodzaju konglomerat różnych innych metod badawczych łącznie z ich technikami, obejmującymi zwłaszcza analizę dokumentów, obserwację, metodę sondażu i metodę dialogową. Technikami wykorzystanymi w obrębie omawianej tu procedury metodycznej były: wywiad, analiza treściowa (zwana też niekiedy metodą analizy treści) - autobiografie, listy, inne formy pisane sporządzone własnoręcznie przez więźniów (udokumentowane pisemnym wyrażeniem zgody na publikację), rozmowa, elementy wywiadu, analiza dokumentów i (pomocniczo) ankieta dla kandydatów do badań psychologicznych. Badania w Zakładzie Karnym (ZK) w Krzywańcu i Areszcie Śledczym (AŚ) w Nowej Soli prowadzone były z przerwami w latach 2008-2011, łącznie objęto nimi 66 mężczyzn i 21 kobiet, czyli populację skazanych liczącą 87 osób. Przedział wiekowy mężczyzn wynosił: 21-57 lat, natomiast kobiet: 24-63 lata.

Przestępczy styl życia - to skutek nieprawidłowości, które wystąpiły w poprzedzających ten etap okresach życia człowieka. Z wypowiedzi badanych przeze mnie wyłania się nade wszystko obraz zaniedbania dziecka już w pierwszym okresie jego życia. To w środowisku rodzinnym, które powinno stanowić fundament prawidłowej socjalizacji, badani zetknęli się najczęściej po raz pierwszy z antywzorcami społecznych zachowań. Jest to prymarne i chyba najważniejsze źródło wystąpienia nieprawidłowości.

Kobieta, lat 28:

[...] później poznałam Ryśka. To tylko była przyjaźn. Z tej przyjaźni urodził się drugi synek D. Było na początku pięknie, że chciało [się] żyć, ale też się zrobił prawdziwy koszmar. [...] Przychodził do domu pijany, robił awantury, bił mnie. Bałam [się] o synka, że podniesie rękę [...]. Jak szedł na kradzieże, to wykorzystałam moment. Wzięłam synka, ubrałam i wyszłam z domu. [...] Pojechałam do szpitala [z] synkiem [...]. Szpital podpowiedział, żeby oddać do domu dziecka i tak zrobiłam [...]. 
$\mathrm{Ja}[\mathrm{k}]$ za każdym razem oddawałam swoje dziecko, przeżywałam jeden jedyny koszmar, nie mogłam na to pozwolić, żeby moje najdroższe pociechy cierpiały przeze mnie; nie mogłam pozwolić na to, wystarczy, że ja cierpiałam. [...] Wiem, że dobrze zrobiłam, że oddałam do rodziny zastępczej.

Kobieta, lat 42:

Z konkubentem mam dziecko, zostały mi odebrane prawa i dziecko jest w rodzinie zastępczej, ponieważ u konkubenta był problem z alkoholem. Teraz na dzień dzisiejszy [...] odbywam resztę kary. Niedługo wychodzę na wolność, aby walczyć o synka, bo tamta dwójka moich dzieci z byłym mężem są dorośli [...].

Kobieta, lat 25:

Kiedy urodziłam córkę, byłam najszczęśliwszą kobietą pod słońcem. Do 4 miesiąca jej życia nie ruszyłam alkoholu - aż do momentu, kiedy to moje koleżanki namówiły mnie na oblanie córki [...]. Wiadomo, kiedy zaczęłam pić, zaczęły się problemy z konkubentem, bo on był przeciwny pijaństwu; ale ja uważałam, że to nic złego jak sobie piwko wypiję, kiedy położę małą spać. Zaczęły się awantury, bo miał mnie ciągle na oku, bo razem z nim pracowałam. Zaczęliśmy się wyzywać, szarpać, a na końcu bić.

Z przeprowadzonych przeze mnie badań wynika, że w biografiach więźniów powielają się scenariusze „przegranego” dzieciństwa, trudnego startu młodych ludzi, którzy już w środowisku rodzinnym zetknęli się z nieprawidłowymi pod względem socjalizacyjnym wzorcami (należą do nich głównie: przemoc, kazirodztwo, alkoholizm, rozbicie rodziny, kryminalna przeszłość rodziców, ale także bieda jako wynik transformacji ustrojowych). Wkraczając w wiek dorastania, jednostki te poszukiwały aprobaty i uznania, jakiego nie doświadczyły w środowisku rodzinnym. W biografiach ujawniających „dobre” dzieciństwo, często doszukać się możemy nieprawidłowości polegających na stosowaniu przez rodziców niewłaściwych technik wychowawczych, np. pobłażliwość wobec zachowań negatywnych bądź aprobatę norm społecznie nieuznawanych.

Przebadani osadzeni nie znaleźli w swej wczesnej biografii osoby wspierającej (matki, ojca, członka najbliższej rodziny bądź opiekuna). Nikt w dzieciństwie w nich nie wierzył i nie wzmacniał pozytywnie. Dlatego też badani nie wspominają o swych dziecięcych pasjach. W rodzinie brak było bliskich więzi 
emocjonalnych, a rodzice (najczęściej matka) jedynie zapewniali minimum bytowe, a nie właściwe wychowanie.

Analiza biografii osadzonych kobiet pokazuje, że częstokroć te z nich, które na wolności były już matkami, zaniedbywały obowiązki macierzyńskie, zaś te, które stały się nimi w warunkach izolacji, nie są dostatecznie (lub wcale) przygotowane do pełnienia takiej roli. Ich niewiedza, brak orientacji w kwestiach opiekuńczo-wychowawczych i nieumiejętność zaspokajania potrzeb dzieci (w różnym wieku) rodzą konieczność organizowania spotkań z lekarzami, psychologami, pielęgniarkami, położnymi, wygłaszania pogadanek i prelekcji poświęconych m.in. roli kobiety-matki w rodzinie.

\section{Edukacja skazanych matek}

Badania wskazują, iż najwięcej matek rodzących w więzieniach pozostaje w przedziale wiekowym od 20 do 30 lat; stanowią więc kategorię kobiet młodych szczególnie podatnych na oddziaływania wychowawcze w zakładzie karnym oraz opieki w czasie życia na wolności ${ }^{17}$.

Przebywanie dziecka wraz z matką w zakładzie karnym jest zgodne z Deklaracją Praw Dziecka (dziecko ma prawo do opieki macierzyńskiej i życia rodzinnego). W Polsce funkcjonują dwa zakłady przeznaczone dla skazanych matek i ich dzieci są to: ZK nr 1 w Grudziądzu, (w którym istnieje jedyny oddział położniczo-ginekologiczny i Dom Małego Dziecka) oraz zK w Krzywańcu (na terenie którego jest zlokalizowany Dom Matki i Dziecka).

W przypadku kobiet pozbawionych wolności, a posiadających dzieci, ustawodawca przewidział reakcję pomocową w art. 87 \$4 Kodeksu karnego wykonawcego. W celu umożliwienia matce pozbawionej wolności sprawowania stałej i bezpośredniej opieki nad dzieckiem organizuje się przy zakładach karnych domy dla matki i dziecka, w których dziecko może przebywać na życzenie matki do ukończenia trzeciego roku życia, chyba, że względy wychowawcze lub zdrowotne, potwierdzone opinią lekarza albo psychologa, przemawiają za oddzieleniem dziecka od matki albo za przedłużeniem lub skróceniem tego okresu ${ }^{18}$.

17 H. Machel, Więzienie jako instytucja karna i resocjalizacyjna, Gdańsk 2003, s. 272.

18 Kodeks karny wykonawczy, uchwalony 6 czerwca 1997, s. 283, http://prawo.sejm.gov.pl/ isap.nsf/download.xsp/WDU19970900557/U/D19970557Lj.pdf, dostęp: 20.01.2017. 
Henryk Machel, który w swoich opracowaniach pisał o roli resocjalizacji i oddziaływaniach penitencjarnych względem osadzonych, zwraca uwagę na fakt, że nie można pozostawić osadzonej samej sobie, trzeba zapewnić jej programy naprawcze, korygujące, kompensacyjne, inaczej całe odbywanie kary oraz funkcja resocjalizacyjna nie ma najmniejszego sensu ${ }^{19}$. Kluczową rolę w tym względzie odgrywa właśnie edukacja, która doprowadzić ma do zmiany sposobu myślenia, działania i funkcjonowania w społeczeństwie. Chęć poddania się takiej transformacji osobowościowej powinna zrodzić się w samej jednostce - wówczas oddziaływania takie są najbardziej skuteczne, ale równie dobrze może powstać pod wpływem osób z jej najbliższego otoczenia, tudzież stanowić efekt przymusu instytucjonalnego, czyli organów kontroli społecznej. Oddziaływania wychowawcze, o których tu mowa, nazywane inaczej oddziaływaniami resocjalizacyjnymi, polegają przede wszystkim na kreowaniu sytuacji i wskazywaniu zadań, które stanowiłyby przyczynek do budowania własnej tożsamości, a więc definiowania siebie, indywidualnej grupy odniesienia i rozpoznaniu swojego w niej udziału. Podstawowym jednak warunkiem pozytywnych rezultatów owych działań edukacyjnych jest uznanie przez jednostkę ich słuszności, zaakceptowanie ich i jednoczesne dostrzeżenie wartość trudu samorozwoju ${ }^{20}$.

Kobieta ciężarna i matka w zakładzie karnym postrzegana jest w sposób szczególny. Wpływa na to jej odrębność psychofizyczna i fizjologiczna w tym okresie, a także specyfika spełnianej przez nią roli ${ }^{21}$. Według regulaminu wykonywania kary pozbawienia wolności kobiety ciężarne i karmiące, a także matki przebywające w zakładzie karnym ze swoimi dziećmi, mają zapewnioną specjalistyczną opiekę, prawo do korzystania z dłuższego spaceru, korzystania z własnej odzieży i obuwia, otrzymywania paczki żywnościowej raz w miesiącu, częstszego dokonywania zakupów.

Dom Matki i Dziecka w ZK w Krzywańcu, gdzie pracuje szereg specjalistów (mowa tutaj o wychowawcach-pedagogach, logopedach, dietetykach, psychologach oraz innych) jest pomocną instytucją. Specjaliści czuwają nad

19 H. Machel, Sens i bezsens resocjalizacji penitencjarnej - casus polski (Studium penitencjarno-pedagogiczne), Kraków 2007, s. 147.

20 Tamże, s. 154-156.

21 H. Reczek, Oddziaływanie wychowawcze wobec osadzonych ciężarnych i matek, w: Problemy więziennictwa u progu XXI wieku, red. B. Hołyst, S. Redo, Warszawa 1996, s. 225. 
rozwojem i wychowaniem dzieci, edukują i wskazują prawidłowe wzorce i korygują negatywne zachowania matek.

W Domu Matki i Dziecka ZK w Krzywańcu idea resocjalizacji przez miłość2 realizowana jest od momentu otwarcia placówki, czyli od 8 grudnia $1978 \mathrm{r}$. Obiekt znajduje się na terenie zakładu karnego, więc w sąsiedztwie widoczne są okratowane okna i drzwi. Wystrój wnętrza w niczym nie przypomina więziennej celi - wyposażenie i urządzenie całej placówki jest bardzo zbliżone do warunków domowych, rodzinnych. Dzieci przez całą dobę przebywają z matkami. Każda matka ma osobny pokój urządzony według własnych potrzeb i gustu ${ }^{23}$. W architekturze placówki nie zapomniano także o miejscach zabawowych, terenach rekreacji. zK w Krzywańcu jest położony wśród lasów, co jest dodatkowym atutem, biorąc pod uwagę spędzanie czasu wolnego na łonie natury. Personel Domu Matki i Dziecka to personel medyczny oraz wychowawczy. Organizacja, obsługa, wyposażenie tej placówki przypominające warunki domowe tworzone są w celu łagodzenia skutków izolacji. Kadra penitencjarna w swoich działaniach na rzecz matek i ich małych dzieci w tych sztucznych warunkach stara się stworzyć najlepsze możliwości psychospołecznego rozwoju owych podmiotów oddziaływań wychowawczych, najbardziej zbliżonych do życia na wolności. Efekty owych zabiegów przynoszą pomyślne i niepomyślne skutki dla przebiegu dalszej życiowej biografii matki, która stoi przed szansą zmiany swojej dotychczasowej sytuacji życiowej oraz dziecka, u którego proces socjalizacji rozpoczyna się w warunkach szczególnych.

Kobiety odbywające karę pozbawienia wolności wraz ze swoimi dziećmi stanowią kategorię kobiet, którym wypełnianie roli matki nie przychodzi łatwo. Pełnienie funkcji macierzyńskich niejednokrotnie przynosi wiele problemów, wynikających z braku odpowiedniej wiedzy, umiejętności i kompetencji. Zapewne rozwiązywanie tych problemów staje się łatwiejsze w sytuacji, gdy pracownicy zakładu karnego uczą przestrzegania elementarnych zasad pielęgnacji, żywienia, dbają o rozwój dziecka i kontrolują zachowania matki. Przynosi to niewątpliwie matce korzyści poznawcze, pozwalające w dalszym biegu macierzyństwa samodzielnie wdrażać w praktykę nabyte umiejętności. Tym

22 Słowa wygłoszone przez Marię Łopatkową podczas otwarcia Domu Matki i Dziecka w Zakładzie Karnym w Krzywańcu.

23 J. Kurowska, Dom Matki i Dziecka w Krzywańcu, „Nasz Głos”, 10 (1999). 
samym chroni dziecko przed ewentualnymi błędami niedoświadczonej w tym względzie matki.

Poprzez macierzyństwo kobieta może stać się bardziej odpowiedzialna (za siebie i dziecko), czuć się dowartościowana jako kobieta, być pobudzoną do refleksji nad swoim dotychczasowym życiem. Może dostrzec lepszą perspektywę życia przed sobą, zapragnąć dziecku wynagrodzić, że urodziło się w więzieniu, może dziecko kochać i zapewnić mu szczęście ${ }^{24}$. Macierzyństwo może stać się czynnikiem osłabiającym lub eliminującym przestępcze zachowania kobiet. Posiadanie dziecka, jego bliskość - jedyna w swoim rodzaju i niezastąpiona może zmienić system wartościowania kobiet. Dziecko dla kobiety może stanowić wartość najwyższą, dla której jest w stanie zmienić charakter dotychczasowej biografii, skierować swoje życie na drogę czynów społecznie akceptowanych. Celem jej życia może się stać wychowanie w miłości małego dziecka.

Kobieta, lat 34:

Pobyt w więzieniu nie zmienił mnie, czuję się tak samo, dobrze funkcjonuję jako matka, jednak nie jest mi łatwo [...]. W zakładzie karnym, jeśli chodzi o odbywanie kary z dzieckiem, warunki nie są złe, nie mogę narzekać. Cieszę się, że jestem tu z synem.

Funkcjonowanie Domu Matki i Dziecka umożliwia dziecku zachowanie wartości najważniejszej - bezpośredniego kontaktu z matką, która zapewnia opiekę i bezpieczeństwo. W całym procesie resocjalizacji skazanej matki fakt macierzyństwa stwarza możliwości pełniejszego i bardziej bezpośredniego kontaktu wychowawczego z osadzoną ${ }^{25}$.Zdaniem Ireny Wesołowskiej-Krzysztofek autentyczny kontakt osadzonych z dziećmi, jest niezwykle korzystny dla nich samych i dzieci. Pozwala łatwiej znosić warunki izolacji poprzez nadanie dodatkowego, konkretnego, realnego celu, do którego może dążyć, przy jednoczesnym umożliwieniu samorealizacji w roli matki ${ }^{26}$.

24 G. Lewandowski, Kobieta i macierzyństwo w warunkach zakładu karnego, „Universitas Gedanensis", 12 (1995) s. 18-24.

25 H. Reczek, Oddziaływanie wychowawcze, s. 485.

26 I. Wesołowska-Krzysztofek, Wpływ kontaktów z dziećmi na deprywację niektórych potrzeb u osadzonych kobiet, w: Problemy więziennictwa w progu XXI wieku, red. B. Hołyst, S. Redo, Warszawa 1996, s. 470-480. 
Pełnienie roli matki powoduje wzrost poczucia przynależności, wzmaga uczucie akceptacji i miłości, która wymaga nawiązania bezpośrednich więzi między jej podmiotami, powoduje wykształcenie kontaktów z niezwykle silnym ładunkiem emocjonalnym. Wówczas skazane kobiety mogą rozpocząć proces analizy własnego dotychczasowego przestępczego życia i zrozumieć, że taki typ biografii może stać się zagrożeniem dla jej aktualnego życia rodzinnego, a nawet jego degradacją ${ }^{27}$.

Personel zK w Krzywańcu, który ma bezpośredni kontakt z omawianą kategorią kobiet więźniarek, wyraża opinie, iż matki odbywające karę pozbawienia wolności wraz ze swoimi dziećmi rozwijają i umacniają więzi macierzyńskie i rodzicielskie, co powoduje późniejsze prawidłowe funkcjonowanie tych kobiet w roli matek na wolności ${ }^{28}$. Optymalną sytuacją jest readaptacja społeczna kobiet wcześniej osadzonych i standardowa socjalizacja ich dzieci.

System programowego oddziaływania tego typu, czyli dla osadzonych matek wraz z dziećmi koncentruje się na czterech obszarach: edukacyjnym, wychowawczym, terapeutycznym i resocjalizacyjnym. W jego ramach osadzone matki są uczone odpowiedzialności, opiekuńczości, właściwych postaw rodzicielskich i spełniania podstawowych potrzeb dziecka ${ }^{29}$. Zadania opiekuńczo-wychowawcze wykonywane przez matki są sprawdzane w wyniku kwartalnych obserwacji postaw macierzyńskich oraz testów, które oceniają, czy dana matka poprawiła swoje relacje z dzieckiem. Bardzo ważnym czynnikiem jest modelowanie wzorca odpowiedzialnej matki. Większość z tych kobiet nie wyniosła z domu właściwego obrazu rodzicielstwa, a co za tym idzie nie są kompetentne, by spełniać podstawowe potrzeby i funkcje dla swojego dziecka. W momencie, gdy matka ma przebywać w zakładzie karnym dłużej niż 3 lata, wtedy organizowane są spotkania z osobami, które chciałyby podjąć dalszą opiekę nad dzieckiem ${ }^{30}$.

27 I. Muszyńska, Odczucie przez skazane dolegliwości kary pozbawienia wolności, „Studia kryminologiczne, kryminalistyczne, penitencjarne", 5 (1976) s. 362-363.

28 Wniosek na podstawie badań przeprowadzonych w Zakładzie Karnym w Krzywańcu, w latach 1979-1995, które objęły one 187 kobiet odbywających karę pozbawienia wolności w Domu Matki i Dziecka.

29 J. Niedworok, Matki więźniarki i ich dzieci w zakładach penitencjarnych: zagadnienia podstawowe, Wrocław 1988, s. 164.

30 A. Matysiak-Błaszczyk, E. Włodarczyk, Macierzyństwo za kratami, „Pedagogika Społeczna", 2004, nr 2-4, s. 51-65. 
W pierwszej kolejności są to osoby z rodziny osadzonej bądź ojca dziecka, a w dalszej - kandydaci na rodziny zastępcze. Matka ma również prawo, by starać się o umieszczenie dziecka w pobliżu zakładu karnego w placówce opiekuńczo-wychowawczej ${ }^{31}$.

Nie należy zapominać, że nawet najlepsze warunki więzienne nie zawsze stwarzają możliwość nawiązania więzi emocjonalnej między matką a dzieckiem. Kobieta funkcjonuje w zakładzie karnym w roli skazanej na karę pozbawienia wolności. Jest na każdym kroku kontrolowana, jej zachowanie i reakcje są w dużym stopniu zdeterminowane sytuacją, w jakiej się znajduje. Również dziecko postrzega matkę przez pryzmat sytuacji więziennej ${ }^{32}$.

Niepokoje może budzić wykorzystywanie działań macierzyńskich uwarunkowanych sytuacyjnie. Pogodzenie dwóch niezwykle odmiennych ról roli matki i roli skazanej jest bardzo trudne. Wymaga podporządkowania się do odgórnie ustalonego porządku więziennego, a zarazem stworzenia dziecku warunków i sytuacji najbardziej przypominających te z życia normalnego. W tych sztucznych warunkach dziecko jest nieustannym obserwatorem sytuacji podporządkowywania matki osobom z personelu więziennego, podejmowania ważnych decyzji za osobę znaczącą dla dziecka, stosowania procedur więziennych nagród i sankcji. Takie warunki tworzą odmienny typ socjalizacji, którą zwiemy więzienną (dysocjacyjną). W wyniku socjalizacji jej podmioty (matka i dziecko) na skutek oddziałujących w zakładzie karnym czynników społecznych, kulturowych czy osobowościowych mogą realizować różne wzory biografii np. wykorzystywać fakt bycia matką dla osobistych intencji. Wachlarz zróżnicowanych scenariuszy zachowań zależny jest od warunków, sytuacji, miejsca i czasu, jednak w głównej mierze od samego podmiotu. Skazane matki niejednokrotnie idealizują siebie w pełnieniu tej roli, przedstawiany przez nie obraz ich macierzyństwa to raczej obraz życzeniowy, a nie rzeczywisty, o czym dowodzą badania Ireny Budrewicz ${ }^{33}$.

31 M. Marczak, K. Mirosław, Funkcjonowanie kobiet w warunkach izolacji więziennej, w: Skuteczność oddziaływań penitencjarnych, red. M. Kuć, Lublin 2009, s. 42-46.

32 G. Lewandowski, Macierzyństwo w zakładzie karnym, „Universitas Gedanensis”, 13 (1995) s. 61-71.

33 Psychospołeczne uwarunkowania zjawisk dewiacyjnych wśród młodzieży w okresie transformacji ustrojowej w Polsce, red. H. Machel, K. Wszeborowski, Gdańsk 1999, s. 320. 
Osadzone w Krzywańcu matki są bardzo zdeterminowane i nastawione na polepszenie swojego zachowania. Korygują i kompensują swoje braki wyniesione z domu na poczet tego, by móc wyjść i wychowywać swoje dziecko w warunkach wolnościowych, a nie izolacyjnych.

Kobieta, lat 32:

Żałuję, że trafiłam do zakładu. Jest mi dużo łatwiej, bo mam przy sobie dziecko. Nie wyobrażam sobie inaczej. Ojciec dziecka odwiedza nas, czeka. Ciągle pracuje jako kierowca. Mam nadzieję, że po odbyciu kary znów będziemy razem. Gdybym miała inny przykład w domu, może mniej strachliwą matkę, która bała się odezwać, dziś byłabym w świetnej pracy, we własnym mieszkaniu. No, ale... pani wychowawczyni mówi, że nie można przekreślać swoich planów i marzeń. Dlatego czekam, aż wyrok dojdzie do końca, zacznę raz jeszcze.

Więź, jaką ma matka ze swoim dzieckiem, oraz codzienne czynności związane z wychowywaniem dają osadzonym namiastkę normalności, której brakuje w oddziałach dla kobiet przebywających bez dzieci. Edukacja osadzonych matek ma na celu między innymi nauczenie jednostki prawidłowych funkcji społecznych, readaptację społeczną, podtrzymywanie kontaktów z bliskimi podczas izolacji więziennej. Ma to również pomóc w tworzeniu właściwych relacji emocjonalnych, a w konsekwencji przestrzeganiu norm społecznych. Sam fakt, że matka przebywa wraz z dzieckiem, może się nim opiekować, wychowywać, czuć więź i bliskość sprawia, że staje się bardziej aktywna jako kobieta i matka. Taka osadzona chce zmienić swoje postawy, być dobrym rodzicem i móc zapewnić odpowiedni byt i spokój emocjonalny swojemu dziecku.

Analizując przypadki kobiet odbywających karę pozbawienia wolności z dziećmi, można zauważyć, że macierzyństwo w izolacji więziennej ma dwa wymiary. Pierwszym z nich jest wymiar resocjalizacyjny, drugim zaś kompensacyjny. Każdy z nich osiągany jest dzięki rozmaitym działaniom edukacyjnym. Osadzone kobiety, chcąc zmienić swoje życie, zminimalizować złe czyny, które popełniły i za które muszą ponieść teraz konsekwencje, starają się zmienić, przechodzą kolejne programy profilaktyczne, naprawcze oraz resocjalizacyjne. Trzeba również zaznaczyć, że sytuacja, w której się znalazły, była podyktowana trudnymi warunkami domowymi, środowiskiem rodzinnym oraz rówieśniczym. Brak było prawidłowych wzorców, respektowania norm i obowiązków. To w domu rodzin- 
nym zostały nauczone bezkarności, roszczeniowości i lekkomyślności ${ }^{34}$. Mimo tego osadzone matki przyznają zgodnie, że są świadome złych wzorców i doświadczeń, które wyniosły z domu. Przede wszystkim chcą zmienić swoje zachowanie w taki sposób, by być dobrymi, wzorowymi matkami, zupełnie innymi, niż te, które poznały same osadzone w dzieciństwie. Uczą się zatem roli matki od podstaw. Mając możliwość odbywania kary pozbawienia wolności wraz z dziećmi, osadzone podejmują próbę korekcji i kompensacji zachowań, włączają się aktywnie w liczne formy pomocowe i warsztatowe, by być lepszymi matkami.

Edukacja pełni zatem kluczową rolę w procesie resocjalizacji poprzez miłość. Nauka jest bazą, bez której proces resocjalizacji nie mógłby przebiega harmonijnie. Należy jednak pamiętać o czynnikach utrudniających edukację skazanych matek i w polskim systemie penitencjarnym eliminować je, jeśli to tylko możliwe. Do takich należą z pewnością lokalizacja zakładów karnych dla skazanych matek oraz postawa społeczna wobec dzieci. Można im zapobiegać chociażby poprzez unikanie tworzenia (wzorem państw takich jak Francja, Niemcy czy Norwegia) domów matki i dziecka bezpośrednio na terenie zakładów karnych, lecz w osobnych enklawach, by stworzyć dzieciom całkowicie normalne i sprzyjające rozwojowi środowisko, dążenie do resocjalizacji poprzez inkluzję społeczną poprzez organizowanie dzieciom np. wyjazdów, wycieczek, kontaktów z rówieśnikami spoza dotychczasowego środowiska (przedszkola publiczne, sale zabaw, place zabaw) czy organizowanie wyjść do bibliotek publicznych (czytanie bajek, konkursy, spotkania z autorami). W edukacji i resocjalizacji skazanych matek chodzi bowiem nie tylko o nie same, ale przede wszystkim o dzieci, które przebywają z matkami tylko przez jakiś czas. Od tego, czego nauczą się w warunkach izolacji więziennej od swoich matek oraz od personelu zależy, jak będą funkcjonowały w społeczeństwie. Edukacja jako integralna część resocjalizacji pełni w tym względzie kluczową rolę i nieprawdą jest to, że proces uczenia się zależy tylko i wyłącznie od samej jednostki. Niewątpliwie, jak wynika z przeprowadzonych przeze mnie badań, potrzebna jest do tego pomoc osób trzecich i instytucji, które dbają o to, by skazane matki oraz ich dzieci brały czynny udział w procesie edukacyjnym, a tym samym miały szansę na prawidłowe funkcjonowanie w społeczeństwie.

34 M. Marczak, Przestępczość kobiet w perspektywie teorii drogi życiowej, w: Resocjalizacja-ciagtość i zmiana, red. M. Konopczyński, B. M. Nowak, Warszawa 2008, s. 189-201. 
Streszczenie: Od pierwszych chwil życia dziecko podlega procesowi uczenia się. Pierwszym wzorcem staje się dla niego matka, od której uczy się podstaw. Nie chodzi tylko o słowa i zachowania, ale także o sposób funkcjonowania w społeczeństwie. Jeśli nie nauczy się tego we wczesnych latach swojego rozwoju, z pewnością dojdzie do zaburzenia procesu socjalizacji. Analiza biografii osadzonych kobiet pokazuje, że ich socjalizacja w większości przypadków była zaburzona, a co za tym idzie - powielały one nieprawidłowe wzorce w dorosłym życiu. Częstokroć te z nich, które na wolności były już matkami, zaniedbywały obowiązki macierzyńskie, zaś te, które stały się nimi w warunkach izolacji, nie są dostatecznie (lub wcale) przygotowane do pełnienia takiej roli. Edukacja jako integralna część resocjalizacji pełni tu kluczową rolę. Skazane matki odbywające karę pozbawienia wolności wraz z dziećmi mają możliwość nauczenia się prawidłowych postaw i zachowań w stosunku do swoich dzieci poprzez udział w licznych formach pomocowych i warsztatowych. Procesowi edukacji powinny podlegać nie tylko one same, ale także ich dzieci, które w warunkach wolnościowych będą musiały umieć znaleźć swoje miejsce w społeczeństwie. Edukacja i resocjalizacja przez miłość matki do dziecka to skuteczna metoda służąca inkluzji.

Słowa kluczowe: edukacja, uczenie się a socjalizacja, resocjalizacja przez miłość, macierzyństwo w izolacji, inkluzja.

\section{Bibliografia}

Benedict R., Wzory kultury, tłum. J. Prokopiuk, Warszawa 2002.

Ciosek M., Psychologia sądowa i penitencjarna, wyd. 2, Warszawa 2003.

Erikson E. H., Identity: Youth and Crisis. New York 1968.

Hurrelmann K., Struktura społeczna a rozwój osobowości, przeł. M. Roguszka, Poznań 1994. Kodeks karny wykonawczy, uchwalony 6 czerwca 1997, http://prawo.sejm.gov.pl/isap. nsf/download.xsp/WDU19970900557/U/D19970557Lj.pdf, dostęp: 20.01.2017.

Kurowska J., Dom Matki i Dziecka w Krzywańcu, „Nasz Głos”, 10 (1999).

Lalak D., Życie jako biografia. Podejście biograficzne $w$ perspektywie pedagogicznej, Warszawa 2010.

Lewandowski G., Kobieta i macierzyństwo w warunkach zakładu karnego, „Universitas Gedanensis", 12 (1995) s. 18-24.

Lewandowski G., Macierzyństwo w zakładzie karnym, „Universitas Gedanensis”, 13 (1995) s. 61-71.

Lis S., Proces socjalizacji dziecka w środowisku pozarodzinnym, Warszawa 1992.

Machel H., Sens i bezsens resocjalizacji penitencjarnej - casus polski (Studium penitencjarno-pedagogiczne), Kraków 2007. 
Machel H., Więzienie jako instytucja karna i resocjalizacyjna, Gdańsk 2003.

Marczak M., Przestępczość kobiet w perspektywie teorii drogi życiowej, w: Resocjalizacja ciągłość i zmiana, red. M. Konopczyński, B. M. Nowak, Warszawa 2008.

Marczak M., Mirosław K., Funkcjonowanie kobiet w warunkach izolacji więziennej, w: Skuteczność oddziaływań penitencjarnych, red. M. Kuć, Lublin 2009.

Matysiak-Błaszczyk A., Włodarczyk E., Macierzyństwo za kratami, „Pedagogika Społeczna", 2004, nr 2-4, s. 51-65.

Modrzewski J., Prakseologiczne modele pomocy jako kulturowy wzór reakcji społecznej na sytuację trudna, w: Koncepcje pedagogiki społecznej, red. T. Frąckowiak, Eruditus, Poznań 1996.

Muszyńska I., Odczucie przez skazane dolegliwości kary pozbawienia wolności, „Studia kryminologiczne, kryminalistyczne, penitencjarne", 5 (1976).

Napora E., Cechy matek pożądane w wychowaniu dzieci, „Problemy Rodziny”, 1995, nr 1, s. 23-29.

Niedworok J., Matki więźniarki i ich dzieci w zakładach penitencjarnych: zagadnienia podstawowe, Wrocław 1988.

Psychospołeczne uwarunkowania zjawisk dewiacyjnych wśród młodzieży w okresie transformacji ustrojowej w Polsce, red. H. Machel, K. Wszeborowski, Gdańsk 1999.

Reczek H., Oddziatywanie wychowawcze wobec osadzonych ciężarnych i matek, w: Problemy więziennictwa u progu XXI wieku, red. B. Hołyst, S. Redo, Warszawa 1996.

Szczurek-Boruta A., Szczurek-Boruta A., Zadania rozwojowe młodzieży i edukacyjne warunki ich wypetniania w środowiskach zróżnicowanych kulturowo i gospodarczo: studium pedagogiczne, Katowice 2007.

Sobczyńska D., Macierzyństwo: wartości i dylematy, w: Humanistyka i płeć. Studia kobiece z psychologii, filozofii i historii, red. J. Miluska, E. Pakszys, Poznań 1999.

Turner J. H., Socjologia. Podstawowe pojęcia i ich zastosowanie, przekł. E. Różalska, Poznań 2000.

Wesołowska-Krzysztofek I., Wpływ kontaktów z dziećmi na deprywację niektórych potrzeb u osadzonych kobiet, w: Problemy więziennictwa w progu XXI wieku, red. B. Hołyst, S. Redo, Warszawa 1996. 